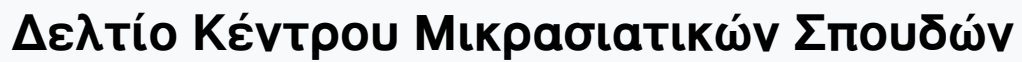

Tó 14 (2004)

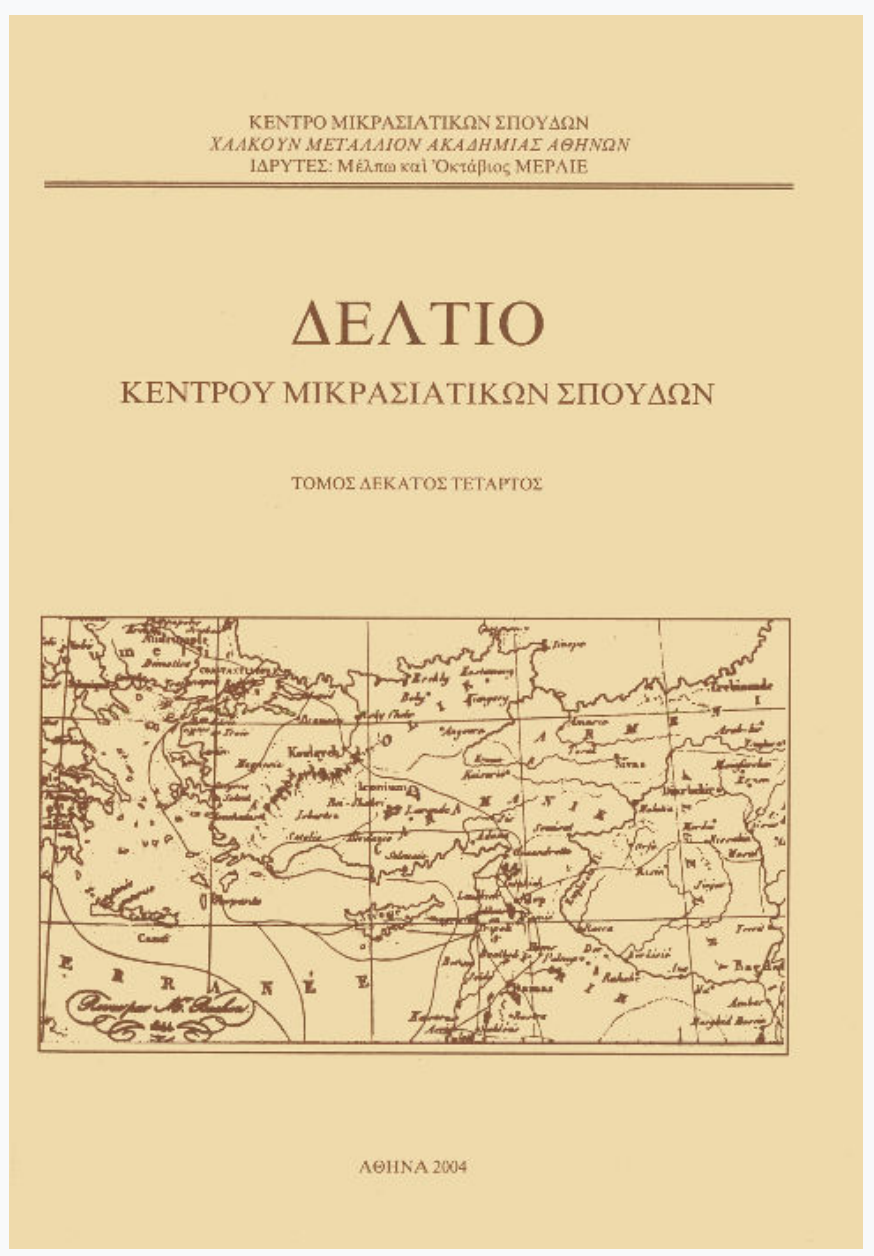

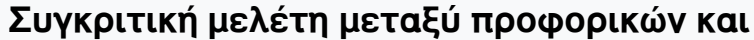

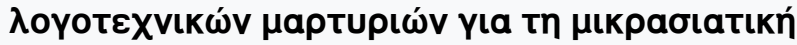 катабтрочń}

\section{Angeliki Sokou}

doi: $\underline{10.12681 / \text { deltiokms.167 }}$

\section{Copyright ( 2015 , Angeliki Sokou}

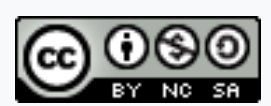

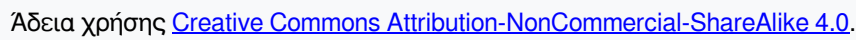

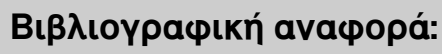

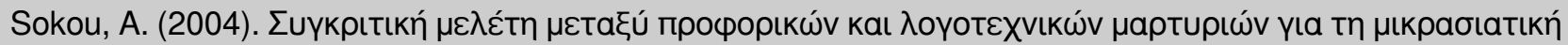

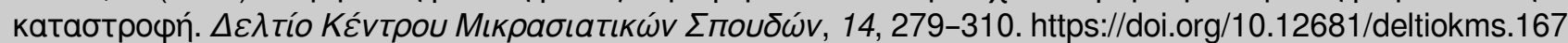




\section{RECONSTRUCTING THE PAST THROUGH UNRELIABLE VOICES. \\ A COMPARISON BETWEEN ORAL AND LITERARY TESTIMONIES ON THE ASIA MINOR DISASTER OF 1922*}

Whether it happened so or not I do not know; but if you think about it you can see it is true. [John G. Neihardt (ed.), Black Elk Speaks].

\section{Introduction}

The relation between history and literature has been the subject of many studies and has raised many questions and disputes. Although it is widely accepted that literature and history are two different disciplines, the actual development of each in and through narrative can reveal great similarities.' It has been argued that history adopts to a certain extent the character of an art, since the arrangement of historical data itself is already a construction which suggests the kind of textual morphologies also used in literature. ${ }^{2}$ In this way, history shares certain characteristics with fiction as a result of being

* This article was based on my Master's Degree (M.A.) undertaken in the Department of Byzantine and Modern Greek Studies in London's King's College (1999). I should like to thank from this position, too, my supervisor Professor Roderick Beaton as well as Maria Nikolopoulou.

1. Lionel Gossman, Between History and Literature, London 1990, p. 233.

2. Peter Haidu, «The Dialectics of Unspeakability: Language, Silence and the Narratives of Desubjectification", in Saul Friedlander (ed.), Probing the Limits of Representation: Nazism and the 'Final Solution', Cambridge, Massachusetts and London 1992, pp. 177-299. 
composed as textualised thought and research. ${ }^{3}$ The association between history and literature becomes more problematic and consequently more challenging when the work of fiction refers to the extratextual world and aims at the representation of real events. In this case, it is literature that merges in a sense into history exercising the referential discourse that the latter uses.

The convergence between history and literature is even more enhanced in the case of oral history, an alternative and supplementary source for historiography, ${ }^{4}$ and of fictionalised testimony. According to John Beverley, the latter is a fictional narrative told in the first person by a narrator who supposedly witnessed the events he or she recounts. ${ }^{5}$ It is evident that both oral history and fiction as testimony draw on narrative genre and historical discourse, since they are concerned with narratives referring to historical events. Both are built through a narrative discourse based on the act of witnessing the testimonial discourse, since the narrators either are, or function as, witnesses who attempt to describe their past experiences with accuracy. In an attempt to denote the truth about reality, fictionalised testimonies exercise an 'unadorned' discourse, a matter-of-fact narrative in order to enable events to speak for themselves. ${ }^{6}$

Can the events actually speak for themselves? The achievement of truth and accuracy in oral and literary testimonies is an issue which needs to be further discussed. In fact, the description of events is conveyed through human discourse whose material differs from the true nature of the facts. Inevitably, language allows us to hear only a person speaking and not the events themselves.?

The ability of literature to represent the actual world has been a problematic issue for literary criticism that gave rise to many different opinions. Wolfgang Iser in his book The Fictive and the Imaginary claims that the reality represented in a literary text is not meant to represent the actual reality. ${ }^{8}$ Whenever realities are transposed into the text, they turn into signs for

3. Haidu, «The Dialectics», op. cit., p. 281.

4. Stephen Caunce, Oral History and the Local Historian, London 1994, p. 7.

5. John Beverley, «The Margin at the Centre on Testimonio (Testimonial Narrative)», Modern Fiction Studies 35, No 1 (1989), pp. 11-28.

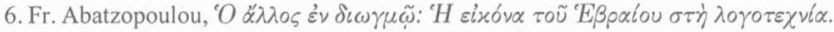
$Z \eta \tau \eta_{\mu} \alpha \tau \alpha$ i $\sigma \tau o p i \alpha \varsigma x \alpha i \mu \nu \theta 0 \pi \lambda \alpha \sigma i \alpha \varsigma$, Athens 1998, p. 100.

7. Abatzopoulou, op.cit., p. 100.

8. Wolfgang Iser, The Fictive and the Imaginary: Charting Literary Anthropology, Baltimore and London 1993, p. 13. 
something else. They are transformed from determinate elements into indeterminate ones by the fictionalising acts of selection, combination and self-disclosure, thus leading to a transgression of boundaries. ${ }^{9}$ Selection crosses the limits of extratextual systems. Combination crosses the boundaries of intratextual fields of reference. Self-disclosure of the text's fictionality transgresses the represented world, indicating that the latter must only be conceived as if it were a real world so that it points to something other than itself. ${ }^{10}$ As a result, the real merges into the imaginary and the reproduced reality creates a reality beyond itself.

The limitations of fiction as testimony to denote the real world constitute an issue that emerged after WWII with the need to represent in literature the experience of the Holocaust." In fact, literature about the Holocaust may provide a significant study in the controversy on the limits of representation, for it sharpens the problematic dichotomy between historical and fictional truth. ${ }^{12}$ The problem which preoccupied the critics was whether it was possible for literary language to represent such an extreme and traumatic experience as the Holocaust. ${ }^{13}$ According to Elie Wiesel, the Holocaust as literary inspiration is a contradiction in terms, since it implies the death of hope, trust, inspiration and language. ${ }^{14}$ Wiesel also stresses the difficulty of the artist to write about a situation that goes beyond its very description. ${ }^{15}$ Similarly, Roland Barthes underlines the limitations of literary language to express 'unspeakable' or 'unthinkable' events. He claims that literature is a well-structured, yet limited cognitive system which can neither go beyond the knowledge of its era, nor say everything. ${ }^{16}$ On the contrary, Foley claims that the Holocaust experience can

9. Iser, The Fictive and the Imaginary, pp. 3-4.

10. Ibidem, p. 19.

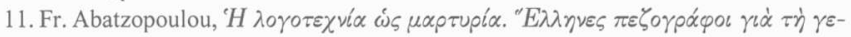

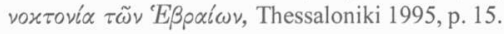

12. Yael S. Feldman, «Whose Story Is It, Anyway? Ideology and Psychology in the Representation of the Shoah in Israeli Literature», in Friedlander (ed.), Probing the Limits, pp. 223-239.

13. Hayden White, «Historical Employment and the Problem of Truth», in Friedlander (ed.), Probing the Limits, pp. 37-53.

14. Elie Wiesel, «The Holocaust as Literary Inspiration», in: Dimensions of the Holocaust, Northern University, Evanston, Illinois 1977, p. 5-19.

15. Wiesel, «The Holocaust», op. cit., p. 7.

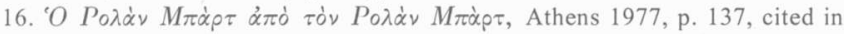
Abatzopoulou, ' $O \dot{\alpha} \lambda \lambda . \circ \varsigma$ हैं $\delta \omega \omega \gamma \mu \tilde{\omega}$, p. 123. 
be represented only by literary sub-genres such as the diary novel or the documentary novel which do not perceive history as a teleological process. Nevertheless, she believes that Genocide cannot be described by the traditional literary schemes of the historical and imaginary novel. ${ }^{17}$ Most critics, however, seem to agree that traditional literary norms based on a rationalistic concept of the world, such as realism, are inadequate to represent extreme and traumatic experiences. ${ }^{18}$

It is widely accepted that an eye-witness is the only person who can represent an event exactly as it happened. ${ }^{19}$ In this light, Berel Lang argues that the most important and reliable works on the Holocaust are the oral testimonies of the witnesses, ${ }^{20}$ an assumption based on the hypothesis that it is possible to discover the truth about history, which seems to ignore the limitations of oral history to reconstruct the past with accuracy. Nevertheless, it has been argued that oral testimonies do not reflect the exact events, but rather are products of the narrator's choices and shaping. ${ }^{21}$ Historians have carried out many researches to evaluate the veracity of eyewitnesses and have discovered that people may sincerely say that they have seen what they could not have done..$^{22}$ More specifically, the informants through their testimonies give, either consciously or unconsciously, a distorted account of what has really occured, because they tend to see only some aspects of it, and to interpret what they have seen according to their viewpoint. ${ }^{23}$ As a witness can never describe everything he has seen, he has to make choices. These choices, however, are to a great extent determined by the cultural values and the

17. Barbara Foley, «Fact, Fiction, Fascism: Testimony and Mimesis in Holocaust Narratives», Comparative Literature 34 (1982), pp. 330-360, cited in Abatzopoulou, 'O

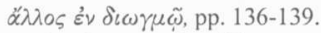

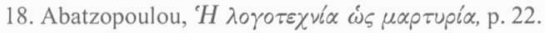

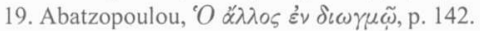

20. Berel Lang, "Historical Writing and the Memory of the Holocaust», in Berel Lang (ed.), Writing and the Holocaust, New York 1988. For the production of oral testimonies referring to the experience of the Holocaust see also Fr. Abatzopoulou, Tó ó $\alpha \propto x \alpha u ́ \tau \omega \mu \alpha$

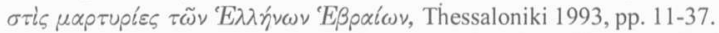

21. Marc Bloch, Apologie pour l'histoire ou le métier d'historien, Paris 1949, cited in

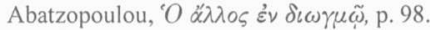

22. Elizabeth Tonkin, Narrating our Pasts: The Social Construction of Oral History, London 1992, p. 40.

23. Jan Vansina, Oral Tradition, London 1965, p. 76. 
tradition of his society. ${ }^{24}$ Rumours and hearsay may become a wellestablished part of the collective memory so that some people come to believe they actually saw an incident which in fact they did not experience. ${ }^{25}$

The subjectivity of the narrator is also enhanced by the effects of memory as a discarding process. Paul Thompson in his book The Voice of the Past: Oral History, cites the results of social psychologists to underline the role of memory in the reliability of witnesses. ${ }^{26}$ Immediately after an event it seems that we can remember a great deal more than later on, while over time reliance on memory becomes inconsistent, as certain memories fade or may have been influenced by subsequent experience. ${ }^{27}$ Another factor that can influence the reliability of a witness is the interaction with the fieldworker. It is very probable that informants may choose their subjects according to their perception of the interview's purpose. The social status of the interviewer may influence their definition of what it is permissible to say. Last but not least, the way a question is raised usually affects the way the interviewee interpretes it, and therefore the nature of the answer. ${ }^{28}$

The fact that an oral testimony necessitates the existence of both an experience and a discourse should also not be overlooked. Putting an event into words indicates an inevitable alteration to that event, since discourse itself can be characterised as a kind of translation. ${ }^{29}$ In this context, the narrator's personal language seems to be a medium for the direct observation and description of the fact. This primary level of mediation is followed by the historian's own mediation. Oral testimonies, in order to be cited in a book, must be transcribed. The transcription of a testimony is also a matter of choices and of interpretation for the historian. ${ }^{30}$ Despite his/her intention to present the unmediated voice of the informant, the written form of an oral

24. Vansina, op. cit., pp. 97, 108.

25. P. Thompson, The Voice of the Past: Oral History, London 1992, p. 137.

26. Ibidem, pp. 110-111.

27. Popular Memory Group, «Popular Memory: Theory, Politics, Method», in Richard Johnson and others (eds.), Making Histories: Studies in History-writing and Politics, London 1982, pp. 205-253.

28. Yvette J. Kopijn, «The Oral History Interview in a Cross-Cultural Setting: An Analysis of its Linguistic, Social and Ideological Structure», in M. Chamberlain and P. Thompson (eds.), Narrative and Genre, London 1998, pp. 142-159.

29. Tonkin, Narrating our Pasts, p. 41.

30. Bloch, Apologie, cited in Abatzopoulou, 'O ḋ $\lambda \lambda_{\circ} \varepsilon^{2} \nu \delta \omega \gamma \mu \tilde{\omega}$, p. 98. 
testimony might well reflect the historian's own evaluation or personal discourse.

Thus, it is possible to argue that neither the historian nor the novel writer may claim to represent the accurate past and mirror reality. ${ }^{31}$ Given the limitations of both literature and oral history in denoting true historicity, the past only emerges in a fragmentary way that it cannot be confined within exact and narrow borders.

Representation of the Holocaust in fiction and history stressed the importance of the oral testimonies and increased the production of fictionalised testimonies and oral history books. In the same way, in Greece, the Centre for Asia Minor Studies started a systematic effort to publish oral testimonies of common people about one of the most crucial and traumatic events in Modern Greek history, the Asia Minor Catastrophe of 1922. The collection of oral testimonies from ordinary people who had experienced the havoc had begun, in 1930. These testimonies were published in two books entitled ' $H$ ' $E \xi \circ \delta \circ$ in $1980,1982^{32}$.

Apart from the production of oral history books, some new literary texts dealing with the theme of Catastrophe appeared in 1962, on the fortieth anniversary of the Disaster. ${ }^{33}$

This study will discuss two of them, $\Sigma \tau \circ \tilde{\nu} X \alpha \tau \zeta \eta \varphi \rho \alpha \dot{\gamma} \gamma \kappa 0$ : $T \dot{\alpha} \sigma \alpha \rho \alpha \nu \tau \dot{\alpha}-$

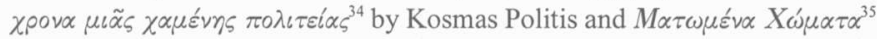
by Dido Sotiriou. Interestingly, during the same period even the literary testimonies that had been published in the immediate aftermath of the

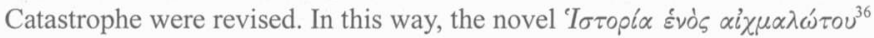

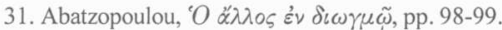

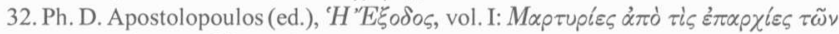

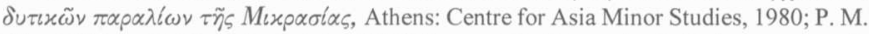

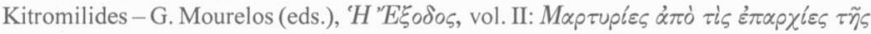

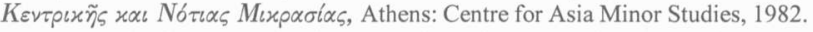

33. For the literary production about the Asia Minor Disaster see Thomas Doulis, Disaster and Fiction: Modern Greek Fiction and the Asia Minor Disaster of 1922, Berkeley 1977.

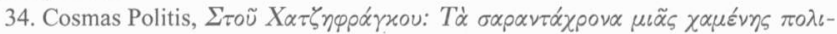
$\tau \varepsilon i \alpha \varsigma$, Athens 1993 (Original edition 1962). All references are to the 1993 edition and will be indicated in my text by the page numbers.

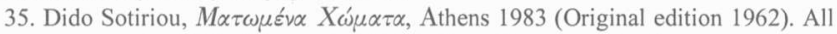
references are to the 1983 edition and will be indicated in my text by the page numbers.

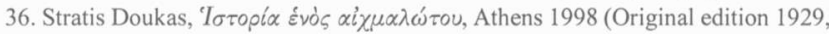


by Stratis Doukas, which was first published in 1929 and revised in 1932, underwent significant changes in 1958 when an afterword was attached. To Noúuspo $31328^{37}$ by Ilias Venezis was first published in the Mytilenean periodical $K \alpha u \pi \dot{\alpha} v \alpha$ in 1924, while its first re-edition appeared in 1931. The book was revised twice more in 1945 and in 1952. It is noteworthy that all the writers mentioned above were themselves refugees from Asia Minor. It could be therefore suggested that their texts reflect the 'refugee discourse'.

This paper examines the relation between the oral testimonies published in ' $H$ ' $E \xi \circ \delta \circ \varsigma$ and the literary texts mentioned above, which belong to the genre of fictionalised testimony, since they have been read as prose-fiction texts referring to historical events with an attempt by the narrators, who function as witnesses, to tell the truth. ${ }^{38}$ The limitations of oral testimony to

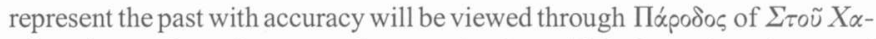

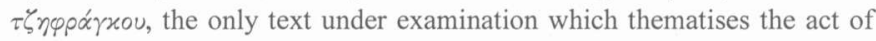
testifying. A further comparison among the texts is carried out to reveal that the 'true' skill of testimonial discourse lies not in its ability to present the unmediated voice of experience, but rather in its power to draw on tradition and myth at all levels of mediation and that literature creates a tradition on which collective memory may draw too.

\section{Mápodos: Bearing Witness to the Act of Witnessing}

The limitations of testimonial discourse in the representation of the past constitute a problematic issue, never mentioned explicitly in the texts under discussion. In other words, neither the oral nor the literary testimonies under examination seem to question the ability of the oral testimony to denote the truth about past events. On the contrary, they show faith in the ability of language to present the actual past experience. The only text, among the texts

revised in 1932 and 1958). All references are to the 1998 edition and will be indicated in my text by the page numbers.

37. Ilias Venezis, Tò Noúuspo 31328, Athens 1989 (Original edition 1931, revised in 1945 and 1952). All references are to the 1989 edition and will be indicated in my text by the page numbers.

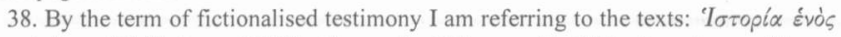

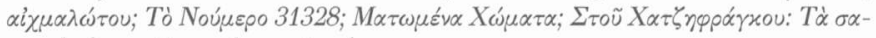

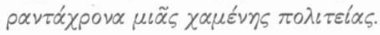


examined here, which challenges the power of testimonial discourse to

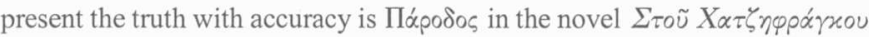
by Kosmas Politis.

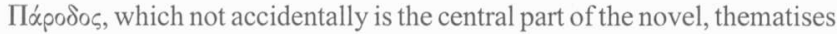
the act of testifying. Yiakoumis, the narrator, talks to a voiceless person who is probably a writer gathering information through oral testimonies about the Catastrophe of Smyrna. The title of the text could imply many different notions, as Professor Peter Mackridge has noticed in his introduction to the book. ${ }^{39}$ It may allude to the passing of time, it may suggest a side-turning or it may refer to the part of the Greek tragedy when the chorus enters the orchestra. ${ }^{40}$ In this sense, Yiakoumis, like the tragic chorus, seems to presage the disaster about to occur. ${ }^{41}$ However, as this section will seek to show, the text may be read in a different context, that of a parody which reveals the impossibility of reproducing the past through reminiscences.

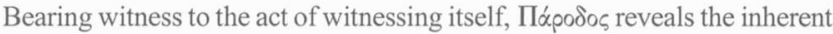
difficulties of oral testimony in representing the past, and highlights the particular problems raised during the process of interviewing in the depiction of truth. The text deals with obstacles such as the relativity of memory, the subjectivity of the informant, the implicit influence of the cultural background and the interaction between the witness and the interviewer.

More specifically, the text demonstrates the double role of both the historian and the informant who are observers and later on narrators of what they have seen or heard respectively. Thus, Yiakoumis is a witness to the Disaster in 1922 and forty years later, in 1962, becomes a narrator of his own experiences. ${ }^{42}$ However, between the informant's two roles come the effects of memory, the 'fallibility' of which seems to be one of the most problematic issues in performing a reliable testimony. Memory is a selective process which records some of the past events and discards others. On these grounds, it has been characterised as the 'sedimented form of past events, leaving traces that may be unearthed by appropriate questioning' ${ }^{43}$

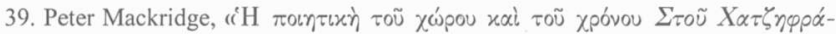

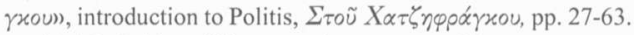

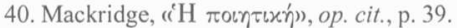

41. Ibidem, p. 39.

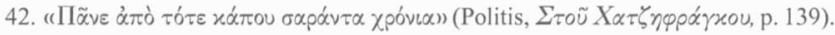

43. Popular Memory Group, «Popular Memory», op. cit., p. 241. 
Most of the obstacles brought up by the function of memory in the representation of past experiences are mentioned in a masterly way in Politis' text. The writer refers to the progressive decline of memory over the years, by exhibiting the awareness of the narrator/witness that certain memories

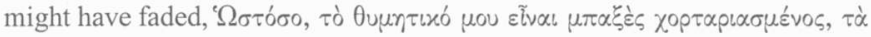

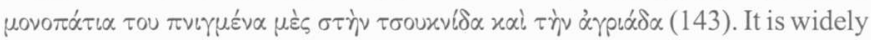
accepted that immediately after an event we can remember a great deal more than later on, as for a redundant phase we have something close to a photographic memory which, however, lasts for only a very brief period. ${ }^{44}$ Yiakoumis stresses once more the long period which has come between the events experienced and the present in order to justify the relativity of his

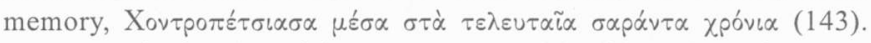
Moreover, the function of the memory process in old age is another issue brought up by the text, "O $\gamma \varepsilon p \alpha \mu \alpha \tau \alpha$ (143). Scientific studies have proved that after the age of thirty memory begins to show a progressive decline. ${ }^{45}$ What is of great importance, however, is that the text itself indicates an awareness of the unconscious

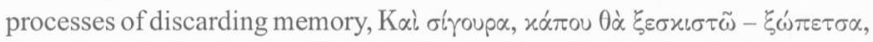

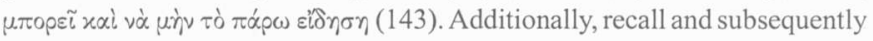
accuracy can be prevented by unwillingness. More precisely, traumatic experiences can result in either a conscious avoidance, or an unconscious repression of displeasing events. ${ }^{46}$ It is in this sense that Yiakoumis postpones the narration of the most dramatic moments of his past. He starts talking about his present life and he goes on to refer to his past by giving particular details about events not necessarily relevant to the Catastrophe. It could be suggested that it is in this context that at the end of each narrative Yiakoumis repeats,

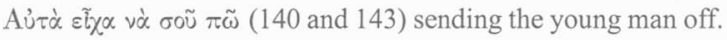

The selective function of memory results to a certain extent in the subjectivity of the informant. ${ }^{47}$ People usually choose to remember what they want to. In other words, the process of memory depends partially upon

44. Thompson, The Voice of the Past, p. 111.

45. Ibidem, p. 116.

46. Ibidem, p. 114.

47. The fallibility of memory is also brought up in other points in the novel: “Tò xaxò

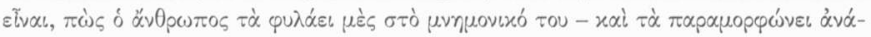

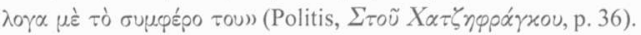


interest. ${ }^{48}$ What is most precisely remembered is what has been sporadically recalled and it is usually material relating to people. ${ }^{49}$ People usually recall episodes that had a specific meaning for them and do not keep in mind dates and details of specific historical events. As a result, many events of importance are neglected in the narratives of witnesses and others of 'lesser importance have a significance attached to them that seems exaggerated' ${ }^{50}$ In

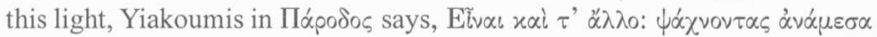

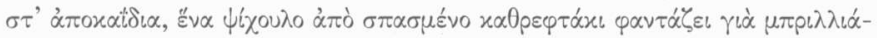

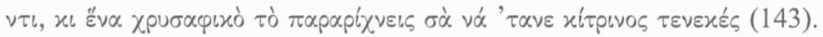

By the same token, Yiakoumis' narrative focuses more on incidents relating to his personal life, than on historical events presented through brief descriptions and dense sentences. In this respect, Yiakoumis refers to prewar life in Smyrna giving a detailed description of a particular custom, namely that of flying the kite. From a literary point of view, it has been noticed that this description functions as a symbol for the ascension of the dead city, ${ }^{51}$ which Yiakoumis also explicitly connects with the Ascension of Christ as depicted by Orthodox traditional art. ${ }^{52}$ However, from another point of view, it can be suggested that extended references to the cultural aspects of life demonstrate the influences of tradition on the choices of the informant. Since an informant may be deeply interested in the traditions of his people, he may on his own initiative assemble a number of traditions and describe them in his testimony. ${ }^{53}$ Tradition is a well-established part of community memory and it is interwoven with reality and myth in peoples' minds to the extent that some people come to believe they have actually witnessed something they have not.

Having stressed the problems raised by the process of remembering, Politis introduces the part referring to the most crucial events by the phrase

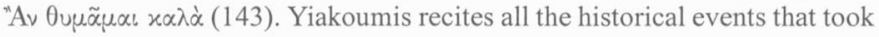

48. Thompson, The Voice of the Past, p. 113.

49. Ibidem, p. 137.

50. Vansina, Oral Tradition, p. 139.

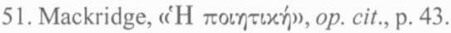

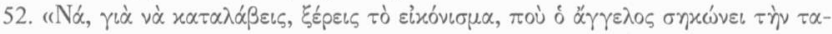

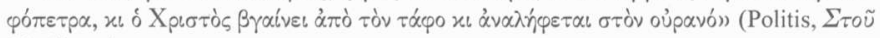

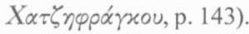

53. Vansina, Oral Tradition, p. 119. 
place a few hours before the Catastrophe of Smyrna framing them once more with incidents from his personal life. In fact, the pivotal theme of his narrative is his relationship with his wife and the very last moments he spent with her. In his description of those latest hours of his town, Yiakoumis incorporates a hearsay he had been told by his barber. The phrase $\sigma x u ́ \beta \varepsilon l$ x $\alpha i$

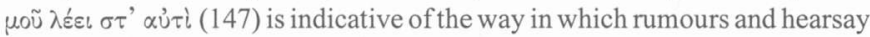
are transmitted among the members of a small community. It can be suggested that such stories constitute a kind of oral tradition which influences people's narratives to such a degree that true and imaginary events are not easily discerned. Bearing in mind that both memory and imagination are ways of comprehending and interpreting events, ${ }^{54}$

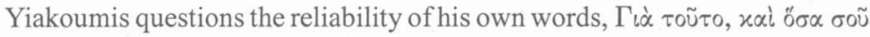

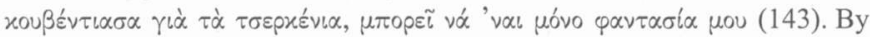
highlighting the informant's instability and uncertainty about his own words, Politis underlines once more the limitations of testimonial discourse to represent the actual past.

Moreover, the text dramatises the interaction between the witness and the historian and its consequences in performing a reliable testimony. Oral history interview is a dialogic discourse, an interactive process created not only by what the interviewees say but also by what the historians do. ${ }^{55}$ Oral testimony is not a monologue, but the narrative's address to an audience. ${ }^{56}$ The presence of the interviewer as the immediate receiver of the testimony dynamically affects the structure and the content of the testimony itself. It is vital that the narrator does not speak in a vacuum, but is aware of the fact that his words are important to someone. By opening the discussion, the fieldworker determines the roles and introduces the basis of narrative

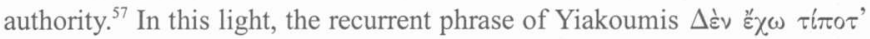

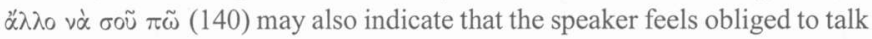

54. Louis O. Mink, «History and Fiction as Modes of Comprehension», in R. Cohen (ed.), New Directions in Literary History, London 1974, pp. 107-124.

55. Alessandro Portelli, «Oral History as Genre», in Chamberlain and Thompson (eds.), Narrative and Genre, pp. 23-45.

56. Dori Laub, «Bearing Witness or the Vicissitudes of Listening», in S. Felman and D. Laub (eds.), Testimony: Crises of Witnessing in Literature, Psychoanalysis and History, New York and London 1992, pp. 57-74.

57. Portelli, «Oral History», op. cit., p. 23. 
only because of a mandate from the historian ${ }^{58}$ Thus, these words could mean 'I only speak, because you ask me to and probably I will say what you want to hear.'

Additionally, it is normally expected that the speaker's attitude will depend on his/her impression of the historian, his social status and his specific motives. ${ }^{59}$ The presence of the interviewer may lead the informant to 'strive for the best possible diction' or to give answers that are expected to be approved by the former. ${ }^{60}$ From the very beginning of $\Pi \alpha$ podos Politis demonstrates the interaction between the informant and the researcher as a social phenomenon which influences the performance of a reliable testimony. In this sense, Yiakoumis expresses respect towards the writers, Toù है $\chi$ $\chi \omega$ бغे

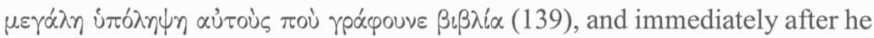
undermines what he and the writer have just said as norms of social

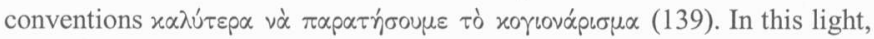

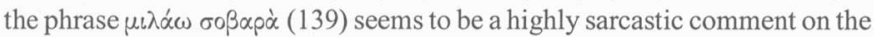
reliability of the witness and more importantly on the ability of language to denote the truth.

As the first person to speak in an oral history interview is the interviewer, the source's narrative can always be seen as a response to the historian's,

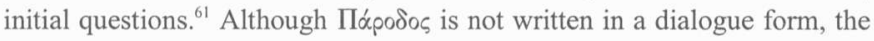
historian's presence in the field can be inferred from Yiakoumis' responses. It is actually the historian's questions and expectations that encourage and form Yiakoumis' narrative. Yiakoumis easily wanders off the point and provides irrelevant information, when he is encouraged to free expression, but the historian's gradual introduction of a set of questions leads him to more specific answers. Yiakoumis focuses on his subjective experience, while the researcher seems to be more interested in the depiction of historical events. This interplay between the unique perception and recollection of events identified with the narrator, and the expectations for an accurate historical representation identified with the narratee/historian highlights the nature and the limitations of oral testimony.

Apart from the interaction between source and historian at the moment of

58. Ibidem, pp. 28-29.

59. Vansina, Oral Tradition, p. 92.

60. Portelli, «Oral History», op. cit., p. 24.

61. Ibidem, p. 28. 
their encounter in the interview, what historians hear and what they say or write is also of great importance.$^{62}$ The historian's presentation of the material in the text is highlighted through a bracketed but still significant, sentence (T⿳亠े冖

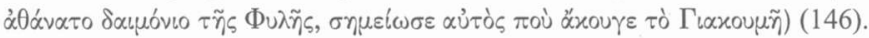
It is the only point in the passage where the action is not conveyed through Yiakoumis' narrative, but through the voice of a quasi omniscient narrator. This arch-narrator is a somewhat disembodied voice and has been characterised as a persona of Politis. ${ }^{63}$ Thus, the text also illustrates the double role of the historian/writer. The words heard by the historian during the interview are transferred and interpreted differently when presented in written form. The subjectivity of the writer often affects the transcription of the testimony. In this way, Yiakoumis' words Tó ' $\delta \alpha \mu \varepsilon \dot{\varepsilon} \tau \dot{\alpha} \mu \alpha \dot{\alpha} \tau \alpha \mu$ ov. ${ }^{\circ} \mathrm{O} \pi \omega \varsigma$

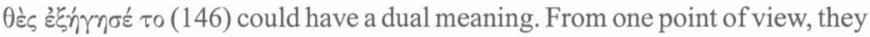
refer to the explanation of the events described, that all services functioned properly even a few minutes before the Catastrophe. However, from another point of view, they can be seen as an implicit comment on the interpreting role of the historian. What the witness relates is interpreted according to the historian's perspective.

To conclude, Пlápodos is the only literary text under discussion to exhibit the nature and limitations of oral testimony. More specifically, it stresses the relativity of the witness' testimony as a result of the discarding process of memory and it demonstrates how consciousness becomes the mediating factor to the recollection of events. Furthermore, the text dramatises the interaction between the informant and the historian and refers to the subjectivity of the latter in interpreting the testimony. Thus, we come to the next question. What are the elements that render the testimony a mediated voice of experience?

\section{Testimony: A Mediated Voice of Experience}

All the texts under discussion aspire to denote the truth by adopting the form of testimonial discourse. Both oral and literary testimonies are supposed to transfer the exact words of their narrators in an attempt to present the unmediated voice of experience. Their explicit aim is to allow the events to

62. Ibidem, p. 23.

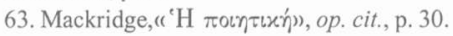


speak for themselves through a discourse which does not include any interpretations or comments on the part of the narrator/witness. However, as the first section has shown, there are certain factors which prevent the informant from being objective in the description of his past. The use of language as a medium, through which the witness constructs his narrative, indicates a primary level of mediation between the experience and the narrative. As oral discourse is later transcribed in order to be cited in the oral history or the literary book, a paradox is introduced. Although the reader has the impression that the narrator relates his first-hand personal experiences, the final form of the testimony is shaped by either the historian or the writer acting as a medium through which the witness 'writes'.

Consequently, there are three levels in which the testimony regarding an experienced event can be divided. The first level is the experiencing ' $I$ ', the witness who is present at the time when the incident takes place. When, however, the witness exercises his role as the narrator of his experiences, he presents a quite different story from the fact itself because the acting of language is an illusory reflection of reality. Thus, he introduces the second level of testimony, or in other words the first degree of mediation. More specifically, as language itself is a constructive system, the reality it produces is a constructed representation. In this way, a narrated experience is by definition a transmission of reality. ${ }^{64}$ It has been suggested that the witness' speech surpasses the witness who is actually the medium of realisation of testimony. ${ }^{65}$ By virtue of the fact that the testimony is addressed to others, the witness, as a narrator, becomes the vehicle of a reality beyond himself. Thus, it could be said that the primary narrative, addressing a small circle of people or the unnamed interviewer only, is relatively mediated or much less mediated than the production of the testimony in a written form.

In transcribing the oral testimony, the writer takes the material, which was narrated to him by the informant, and gives it a written form. This is the second degree of mediation which appears to be much stronger. The final form of the testimony is a written text whose concept implies a stable entity that exists independently of all those who interpret it. The writer's intervention is the one that presents the story as something not individual but

64. Peter Lamarque and Stein Haugom Olsen, Truth, Fiction and Literature, New York 1994, p. 239.

65. Shoshana Felman, «Education and Crisis, or the Vicissitudes of Teaching», in Felman and Laub (eds.), Testimony, pp. 1-56. 
representative, as something that makes an appeal to people. In transcribing the oral testimony for publication either as an historical source, or as a literary text, the writer makes claims for greater significance. After having been written and published, the testimonies become a kind of monument that addresses the public. The process by which the informant's speech, addressing a determinate audience, is turned into a discourse addressing a broader audience, namely the public, indicates the intentionality of the writer. The intentionality of the writer is the only criterion for the reader to distinguish a literary work from an individual narrative and, according to Genette, it is usually denoted in the paratexts of a book. ${ }^{66}$

The mediating role of both the historian and the literary author in giving the oral testimony a written form is an additional factor opposing the aspirations of the testimonial discourse to represent the actual past. The professed intention of the literary writer and the historian to re-tell the truth about the historical facts is communicated to the reader usually in the paratexts provided in the books under examination. However, sometimes these paratexts undermine the immediacy of the discourse by drawing attention to the role of the person who composes the text. This part of the dissertation focuses mostly in the paratexts in order to show that, although the testimonies under discussion present themselves as unmediated voices of experience, they actually reach their readers as the mediated voices of witnesses shaped by a writer. The section also seeks to investigate to what extent this final shaping implies intentionality on the part of the writer.

Oral history, according to Alessandro Portelli, "begins in the orality of the narrator but it is directed towards and concluded by the written text of the historian' ${ }^{67}$ Both the narrators' orality and the historians' intervention are underlined in the introduction to the first volume of ' $H^{\prime} ' E \xi o \delta \circ$ s. Testimonies gathered in the book are the narratives of common people from the western coastline of Asia Minor who have told their personal stories to fieldworkers. Testimonies have been classified in three volumes by geographical region. The second volume includes testimonies of people from central and south Asia Minor, while the third deals with testimonies from the former inhabitants of Pontos. The historians are those who re-tell the reminiscences of the

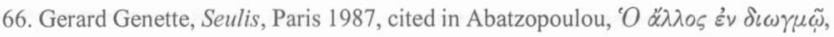
p. 101.

67. Portelli, „Oral Historym, op. cit., p. 25. 
witnesses ${ }^{68}$ Furthermore, the text underlines the double value of the written testimonies, stressing in this way the linguistic expression of the narrator as something different from the experience itself. ${ }^{69}$ Interestingly, the mediating role of both the narrator and the writer in the construction of a testimony is demonstrated in the following sentence:

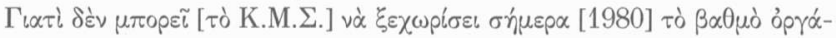

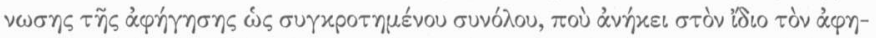

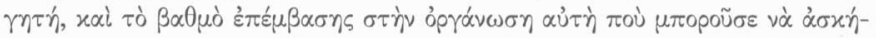

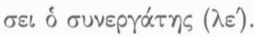

The introductory text, in this way, recognises the use of language as a medium through which the experience is altered.

However, the historian's intervention in a book of oral history must be erased from the published text in an attempt to create the illusion that the witness is speaking directly to the reader. ${ }^{70}$ Portelli has stressed the importance, in achieving this goal, of the paralinguistic elements of the interview as vehicles for carrying the informant's attitude. ${ }^{11}$ However, the prevailing tendency among the researchers is to smooth the narration by neglecting the paralinguistic features that give oral sources a surplus vis-à-vis the written ones. ${ }^{72}$ It can be deduced that in the case of oral history accuracy is considered to be the aim of all transcribing and editing, but still there is a problematic issue. A transcript faithful to sounds might turn the speech into an unreadable page and this can hardly be characterised as accurate. ${ }^{73}$ In this context, the oral testimonies of ' $H$ ' $E \xi \circ \delta \circ \varsigma^{\prime}$, according to the introduction to the first volume, underwent few but essential alterations in order to be transformed into comprehensible and readable written texts. ${ }^{74}$ On the other

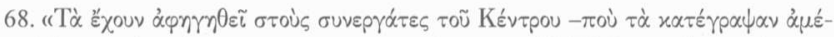

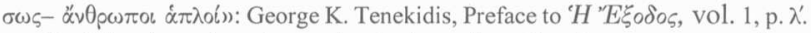

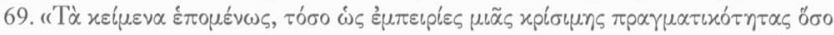

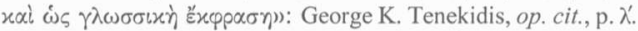

70. Portelli, «Oral History», op. cit., p. 32.

71. Kopijn, «The Oral History Interview», op. cit., p. 148.

72. Ibidem, p. 148.

73. Portelli, «Oral History», op. cit., p. 34.

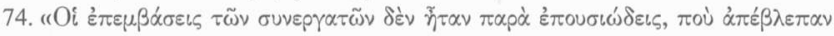

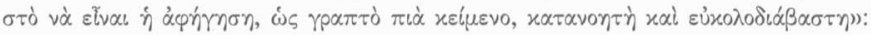
George K. Tenekidis, op. cit., p. $\chi$. 
hand, the historians maintain that they tried not to change either the content or the form of the narratives, in their attempt to preserve the accuracy in the written testimonies. ${ }^{75}$

As it becomes apparent, the historians' interventions in the oral testimonies of ' $H^{\prime \prime} E \xi \circ \delta \circ \varsigma$ are silent and invisible, but can still be traced in the texts. For instance one rarely finds the expected regional linguistic varieties in the written testimonies, since the language is very homogenous and close to standard (xoเvi) modern Greek. ${ }^{76}$ Specifically, in some written texts a few words or even whole phrases in Turkish are transferred unedited, while their translation is provided in footnotes. This, however, leads to the assumption that the speaker might have used more Turkish idioms which were translated directly into Greek, according to the information given in the introduction. ${ }^{77}$ This is evident in the testimony of Afroditi Yiannaki, where the informant seems to have used both Greek and Turkish words to re-tell the utterances of a Turk. ${ }^{78}$

Hence, representing the linguistic idiom is one way of conveying the accuracy of the testimony, but translating or even making the spoken word accessible to the reader through punctuation and other paralinguistic elements constitutes a silent intervention. Punctuation is used in a written text in order to separate the sentences and to make the meaning clear. It is in this context that one should view the long sentences with frequent punctuation in ' $H^{\prime} ' E \xi_{0-}$ $\delta \circ \varsigma$, a phenomenon absent in the oral discourse. Single sentences separated by dashes, commas and semi-colons are very common in the texts. ${ }^{79}$

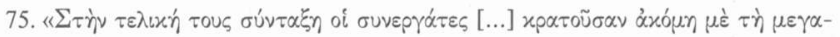

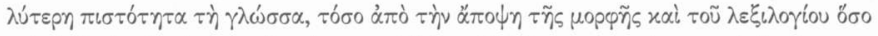

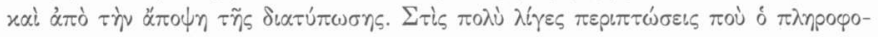

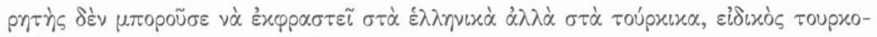

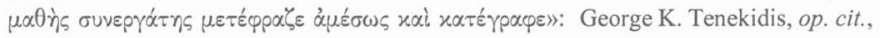
p. $\lambda^{\prime}$.

76. It is widely known that some of the refugees did not speak Greek at all, but even if they did, their dialects were various and peculiar such as Pontic and full of distinctive linguistic characteristics. George Th. Mavrogordatos, Stillborn Republic: Social Coalitions and Party Strategies in Greece, 1922-1936, Berkeley 1983, p. 193.

77. See footnote 76 .

78. For instance the word $\tau \sigma \alpha \mu \pi$ oúx means quickly as the translation indicates: George K. Tenekidis, op. cit., p. 197.

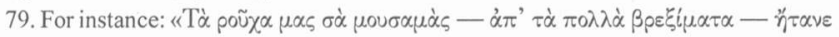


Indicative of this quasi silent intervention is the use of exclamation marks and dots which aim at expressing the intonation of the speech in the written texts. ${ }^{80}$ The choice of different ways of conveying direct speech is also noteworthy. The spoken exchanges are either in quotation marks or in dialogue form. Moreover, the absence of grammatical and syntactic errors normally to be expected from people who lack formal education must not be overlooked. Finally, the separation of the texts into paragraphs is yet another indication of the researcher's mediating role. ${ }^{81}$

By the same token, in the oral testimonies first published in 1964 under the title $O$ Koıvòs Áros ${ }^{82}$ paragraphs and punctuation are used to smooth out problems raised by the oral discourse, although the information given in the introduction draws attention merely to insignificant corrections done on some of the testimonies written by the informants themselves under the ${ }^{83}$ Elli Papadimitriou, the person who had the inspiration of this work and gathered the testimonies, stresses the absence of any kind of mediation in order to illustrate the accuracy and immediacy of the discourse, although a kind of intervention can be detected in the texts themselves. ${ }^{84}$

The professed accuracy and immediacy of the testimonies indicates the desire on the part of the editor to present not only facts, but also a traditional discourse representative of the collective whole. In her introduction, Papadimitriou emphasises the significance of the oral discourse as a

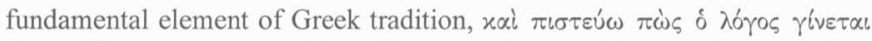

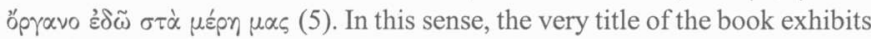
its aim to be read as a collective testimony where the individual voice is mingled together with the collective through a traditional discourse. That is

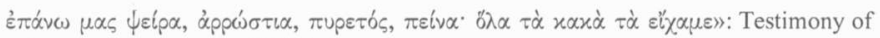
Marianthi Karamoussa, 'H 'E ${ }^{\prime} \circ \delta \circ \varsigma$, vol. I (pp. 187-195), p. 193.

80. Examples can be found in the testimony of Panayiotis Marselos, op. cit., pp. 1119.

81. In relation to this structural form, see Thanassis Valtinos, 'O $00 \varkappa \omega \sigma \tau \dot{\alpha}$, Athens 1994. The literary texts are not separated into paragraphs in an attempt to reflect the fluency of orality of the real testimonies.

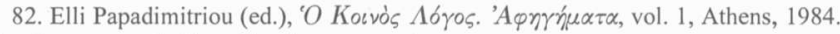
All references are indicated by the page numbers.

83. Papadimitriou, op. cit., p. 4.

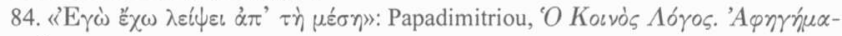
$\tau \alpha$, p. 5 . 


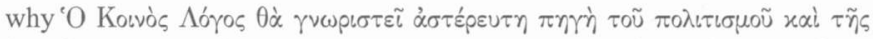

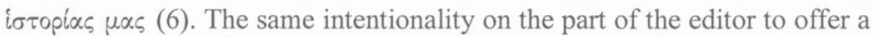
work of both historical and cultural significance is also to be discerned in ${ }^{\prime} H$

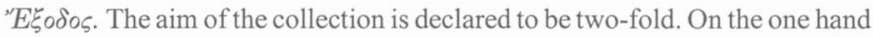
it constitutes a source of historiography and on the other it offers a sample of collective discourse due to the linguistic value of the texts. ${ }^{85}$ In this light, the discourse of the texts is explicitly identified with the title of the above book,

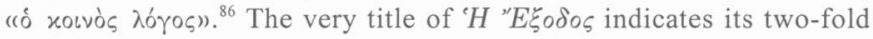
significance as well. The editors, in the introduction, underline not only the historical, but also the biblical allusions. Thus, the title points to the uprooting of the Greeks of Asia Minor after the convention of the compulsory exchange of populations in 1923 and also alludes to the biblical Exodus emphasising the power of tradition. ${ }^{87}$

More importantly, Venezis was the first writer to introduce the biblical allusions in fictionalised testimony as pointers of Greek culture and tradition. Each chapter of the 1952 edition of Tò Noúuspo 31328 is entitled by verses from David's psalms. ${ }^{88}$ Venezis' work can therefore be related to the biblical allusion of 'H 'E $E$ odos.

However, the fact that the psalms were added to the book some time after the first edition indicates the intentionality of the writer. A comparison among the editions of the book demonstrates the different levels of mediation and reveals this intentionality as a result of the second level of mediation. In Tó Noúrepo 31328 the three levels of bearing witness are mediated by the same person, as the introduction to the edition of 1945 underlines. The witness is identified with both the narrator and the author, but they can still be chronologically separated. In this way, one can distinguish Ilias, the young man who experiences captivity in the labour battalions in the immediate aftermath of the Catastrophe, from Venezis, the narrator who writes his story for the first time addressing a small audience in $1924{ }^{89}$ The first version was

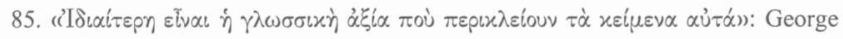
K. Tenekidis, op. cit., p. $\lambda \delta^{\prime}$.

86. George K. Tenekidis, op. cit., p. $\lambda \delta^{\prime}$.

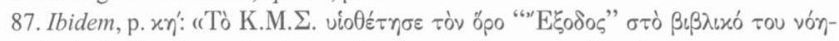

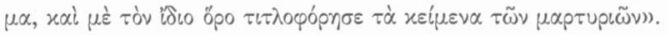

88. The edition of 1945 does not contain the psalms, Ilias Venezis, Tò Noú $\mu \varepsilon p o$

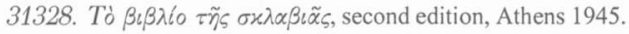

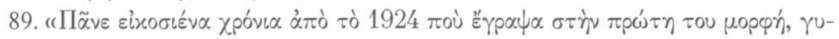




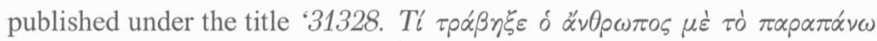

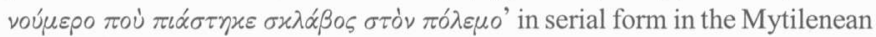

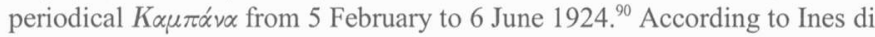
Salvo, the primary version of 1924 seems to be closer to the experienced events. The writer composed the text without a specific plan, by recalling single episodes from his memory. In this light, the adhesion to the recalled incidents has been characterised as direct and emotional. ${ }^{91}$

In 1931, however, Venezis, as writer, introduces a systematic organisation of the already used material. ${ }^{92}$ In addressing his work to the general public, the writer claims greater significance and uses the means which will make an appeal to the collective consciousness. For this purpose, he altered his personal story in order to present it as representative of the collective whole. In the 1931 version, Venezis elaborated on the original narrative of 1924 and added further narratives. ${ }^{93}$ New data relating not only to historical events, but to the folk tradition of Anatolia as well were inserted into this edition. One can also detect an intention - still tacit though - on the part of the author to promote a pacifist message. ${ }^{94}$ In the 1945 edition a preface was added which draws attention to the veracity and authenticity of the text and presents it as an autobiographical testimony. After all, Venezis himself confessed that although his narrative was based on real events, he had made some changes in order not to offer a purely superficial reproduction of facts. ${ }^{95}$ For example, the presentation of the thoughts and feelings of several people as those of the hero, ${ }^{96}$ indicates the author's intentionality to establish his work as

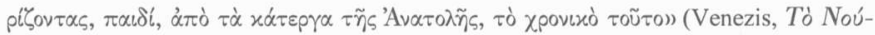
нвро 31328, p. 13).

90. The information given is based on the study of Ines di Salvo which examines the specific changes made between the 1924 edition and that of 1931: Ines di Salvo, Tò Noú$\mu \varepsilon$ po 31328 di Venezis: Dalla prima alla seconda redazione, Palermo 1978, p. 6.

91. Ibidem, p. 9.

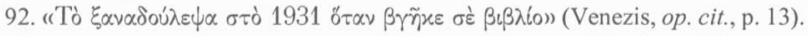

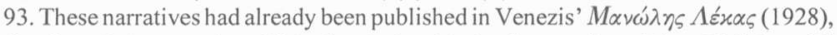
a collection of short stories which also dealt with the theme of captivity, Di Salvo, Tó Noúuspo, pp. 8-9.

94. Di Salvo, Tò Noú $\mu \varepsilon p o$, p. 10.

95. The information is based on an interview that Venezis gave to the newspaper Tó $B \tilde{\eta} \mu \alpha$ on 19/12/1950, cited in Di Salvo, op. cit., p. 10.

96. Ibidem. 
representative of the collective mentality. Furthermore, the juxtaposition of the raw reality and the use of literary conventions in the text, ${ }^{97}$ underlines even more Venezis' intention to write a literary text which will reflect the collective mentality and will address the public. The adding of psalms to the 1952 edition stresses the intentionality of the author to link his book with the tradition and to present it as a work representative of Greek civilisation. ${ }^{98}$

In the same way, in the preface to $M \alpha \tau \omega \mu \varepsilon^{\prime} \alpha \alpha X^{\prime} \omega \mu \alpha \tau \alpha$ Sotiriou's professed intention is to contribute to the reconstruction of a lost world by presenting the voice of a representative of the collective whole. In this context, Manolis Axiotis, the narrator, is explicitly identified with the representative of the

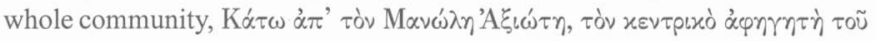

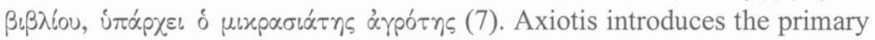
level of mediation with his narrative. Moreover, this mediation is enhanced by the fact that the narrator writes his own first hand experiences instead of relating them to the author. ${ }^{99}$ Here, as in the previous testimony, the first level of mediation is introduced through a written discourse, a fact which might lead to a significant alteration of the experienced event itself.

Nevertheless, Sotiriou explicitly claims to be re-telling the written reminiscences of her narrator. ${ }^{100}$ Thus, a second degree mediation is indicated by the fact that Sotiriou re-writes Axiotis' testimony enriching it with information obtained by other witnesses' testimonies. ${ }^{101}$ The goal of this act is to transform an individual discourse into a representative one, so as to make an appeal to the collective mentality. Presenting herself as a collector of oral

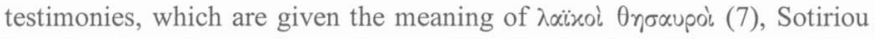
intends to contribute to the continuum of the Greek culture. However, adding a political interpretation of the facts to the text through the voice of Axiotis ${ }^{102}$

97. Beaton, Introduction, pp. 139-140.

98. The elements of tradition would probably make an appeal to the consciousness of ordinary people and would act as bearers of a pacifist message. Moreover, the fact that the chosen psalms refer to sufferings of the Jewish people may indicate Venezis' interest in the Holocaust.

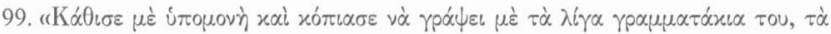

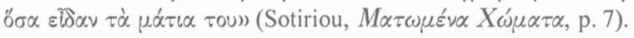

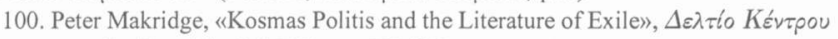

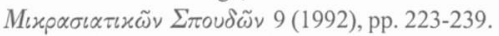

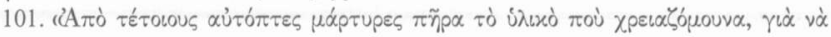

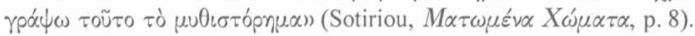

102. Beaton, Introduction, p. 241. 
invites a historical reading of literature. ${ }^{103}$

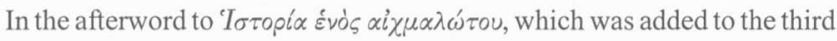
edition of 1958, Stratis Doukas declares that he had also used a genuine oral testimony to write a literary text. Doukas is the only author to admit his intervention in the construction of the written text and at the same time to claim that he is presenting a true testimony. ${ }^{104} \mathrm{In}$ his paratext all the levels of mediation presenting a written testimony are underlined. More specifically, Nikolas Kazakoglou narrates his story to Doukas who writes it down at the same time, in order to preserve the immediacy of the narrator's discourse. Still, the writer stresses his intervention in the primary narrative by the words

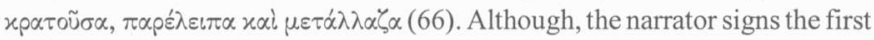
written version of his story, Doukas admits that he has changed even the signature from Kazakoglou to Kozakoglou. Moreover, Kazakoglou re-tells the beginning of his story which was missing from the first written text, but

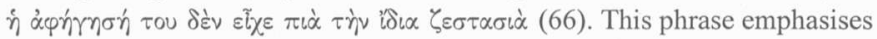
the first level of mediation by indicating that a narrative about an experienced event can never be the same as the event. In this sense, it could be suggested that Kazakoglou is the experiencing ' $\mathrm{I}$ ', but Kozakoglou is the primary narrator who inevitably alters the experienced event, while Doukas, as the writer of the book, introduces the second level of mediation.

The authorial intervention is mentioned many times in the paratext and it is highlighted through the different editions of the book. Doukas re-writes the story by dictating it to his cousin in order to preserve the authenticity of the oral discourse, but he defends departing from the literal truth for the sake of the story. ${ }^{105}$ Thus, the story in the editions of 1929 and 1932 is presented as having

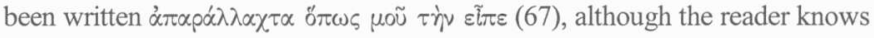
that this is not the case. In the edition of 1958 , however, the changes which were made by the writer are denoted explicitly in the paratext. ${ }^{106}$ Yet, the popular

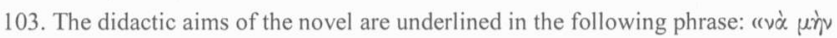

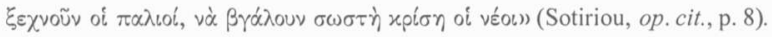

104. Drawing attention to the writer's role in composing a novel has been characterised as an innovative technique absent from the literature of realism (Abatzopoulou, $O$

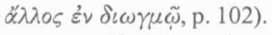

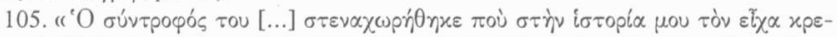

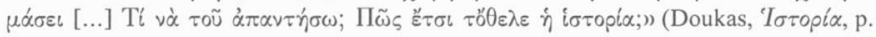
67).

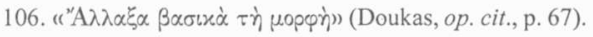


language seems to be of great importance for Doukas, as his aim is to preserve the popular charm of his hero's discourse by 'purifying' it. ${ }^{107}$ Doukas' intentionality results in the presentation of his text as a hybrid, an innovation of an invented ideal oral testimony which reflects the collective voice.

In conclusion, all the testimonies under examination reveal the necessity of two mediators, one to narrate the experienced incident and one to be responsible for the transformation of the oral discourse into a written text. As a consequence, the testimonies presented by oral history and literature are mediated voices of experience. However, it is the author's intentionality that determines the form of each work which can be traced not only in the form, but also in the selections he or she makes as far as content is concerned. This brings us to the next question. What do the selected themes of oral history and literature reveal?

\section{Collective Memory versus Historical Truth}

It has been argued that history is a discipline different from and superior to collective memory and in this context, memory has been treated as a primitive phenomenon. ${ }^{108}$ However, such identifications are equivocal, since memory and history are strongly related and deeply interwoven in the way people perceive and reproduce historical events. This section examines the nature of collective memory and its relation to history and tradition, focusing on the fact that testimonial discourse draws on myth and tradition at every level of mediation. More specifically, the chapter deals with the recurrence of common thematic motifs both in oral and in literary testimonies and seeks to reveal the relation of these similarities and the reason of their existence.

Among the descriptions of violent scenes about the Asia Minor disaster, there are some narratives both in oral and in literary testimonies under discussion, that could be characterised as humane. These stories or events deal mainly with the theme of friendship between individual Turks and Greeks from Asia Minor and appear with almost the same content in three

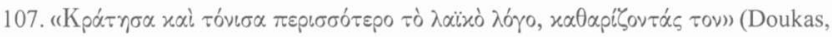
op. cit., p. 67).

108. Tonkin, Narrating our Pasts, pp.118-119. For the relation between history and collective memory see also Jacques Le Goff, History and Memory, trans. by S. Rendall and E. Claman, New York and Oxford 1992, pp. 79-147. 
texts, one of which is an oral testimony and the other two are not unintentionally -as the paper will seek to show- literary texts. The first such instance appears in Anastasis' Charanis oral testimony in 'H ' $E \xi \circ \delta \circ \sigma_{5}$ and in two literary texts, Tò Noú $\mu \varepsilon \rho o 31328$ and $M \alpha \tau \omega \mu \varepsilon \dot{\varepsilon} \alpha \alpha \omega \mu \alpha \tau \alpha$. It refers to the relationship developed between the narrator/captive in labour battalions and a doctor of the opposite camp. The latter helps the former either by curing him or by giving him sick leave to stay away from the atrocities of the war. Although there are differences in the stories, the prevalent element in all three is the presentation of the doctor as a deus ex machina who saves the narrator at one of the most dangerous moments of his life. The second common story again presented in one oral testimony and in two literary texts namely, in

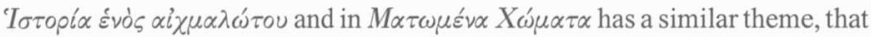
of a friendship developed between a Greek and a Turk under specific

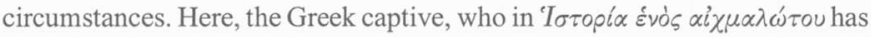
escaped captivity by pretending to be the Turk, works for the Turk during or after the war. The latter is presented once again as a friendly, and helpful figure. More specifically, these passages deal with the moments of the narrator's departure. The Greek has decided to leave instead of staying with the Turk, who seems to have loved him as his own child and who wishes to arrange a marriage between him and a girl from his family.

Having stressed the above thematic similarities, it is challenging to examine why these stories are repeated. In answering this question, there are two extreme explanations. One possibility is that these events actually took place several times, which is why they keep re-appearing in the narratives. This purely historical aspect implies also that literary testimonies reveal the truth about real events which were witnessed by the narrator. On the other hand, the extreme literary explanation would be that the dynamics of storytelling make the specific story recur. In other words, the stories bear repeating, because they are 'good' stories to be narrated. Their quasi fairy tale structure and theme make the stories re-appear whether or not they had actually occurred. Theoretical studies on the nature and function of narrative have tried to explain what are the required features of a 'good' story which make it followable. ${ }^{109}$ Narrativists have stressed the techniques of telling, the sequential form which bears a beginning, a middle and an end, the elements of expectation, surprise and resolution, and the acceptability on the reader's

109. Mink, «History and Fiction», op. cit., p. 110. 
part as the fundamental stuff of a story to be followed. ${ }^{110}$ According to Mink, stories bear repeating 'in some cases because of the pleasure they give, in others because of the meaning they bear'."'

Based partially on the above statement my argument will show that the repetition of two common themes in one oral and two literary testimonies is not accidental. In examining the interrelation between the dynamics of the testimonies under discussion, I will try to prove that the similarities in question are the result of common conceptualisation of experience, rather than of a common experience. The appearance of the specific stories in the oral testimonies means that the narrated events have occurred in the same or in a similar version, but their recurrence in at least two literary texts implies a kind of cultural function. The recurrence of particular thematic motifs in story-telling form discloses the way history is perceived and preserved by collective memory. The stories that people want to hear over and over again are those which shape the collective consciousness of a community. ${ }^{112}$ According to Mink, individuals understand history through the 'configurational' mode of comprehension that is, the ability to balance in their minds a number of different elements. ${ }^{113}$ As the state of knowledge presupposes the act of comprehension, stories seem to be one of the easiest ways for people to understand and recollect historical events which are endowed with different story-meanings through emplotment. ${ }^{114}$

In understanding the function of the thematic similarities and their interrelation it is useful to consider why the particular stories have been selected. The notion of selection is implied both in oral and in literary testimonies and takes place at both levels of mediation. At the first level, the notion of selection is identified with the narrator's preference to tell a specific story rather than another. Narrative involves selection, since no one can describe everything he/she has seen. In making this choice, the narrator emphasises the meaning he considers important to the described event. ${ }^{115}$ Experience is usually organised in stories which carry the significance given

110. Ibidem, p. 120.

111. Ibidem, p. 120.

112. Ibidem, p. 120.

113. Ibidem, p. 117.

114. White, «Historical Employment», op. cit., p. 38.

115. Vansina, Oral Tradition, p. 97. 
by the collective mentality to events. ${ }^{116}$ Since people are bound to be influenced by this significance, it can be suggested that individual narratives about past events constitute an elementary form of popular memory. Rumours and hearsay survive, when they make sense to people and become a wellestablished part of community memory. The stories which illustrate the figure of the good Turk make an appeal to people's consciousness. They demonstrate the way common people understand history. All Turks are not enemies in the eyes of the Greeks of Asia Minor, since they had been living together for many years.

The selection of 'non-witnessed' incidents at the first level of mediation can be traced in both the oral testimonies under discussion. The informant who narrates the incident with the doctor refers to a dialogue which has taken place between the doctor and a person familiar to the narrator. Although, the narrator has not witnessed the specific scene, he cites the whole dialogue in his testimony as if he were present. In the second testimony the example is more striking, since the narrator exercises in a way the function of a literary text. More specifically, he interrupts his narrative in order to present someone else's story dramatically in a way reminiscent of the so-called embedded story in literature. Thus, the particular extract from ' $H^{\prime} ' E \xi \circ \delta \circ \varsigma$ is not a typical case of oral testimony. This story could be composed of rumours which had adopted the form of a well-established tradition in the collective memory. Equally, the event might actually have taken place. One could also hypothetically suggest that the early published text of Doukas had contributed to the creation of the particular folk tradition, an assumption that remains unprovable however. Whatever the case might be, the question posed on the issue of the story selection is not interesting for the true origins of each story, but rather for what it reveals about the story function as a cultural element. It would be an oversimplification, however, to argue that ordinary people who describe their traumatic experiences arrange their material according to some literary plan. Oral narratives draw unconsciously on a wide range of folk elements present in contemporary popular culture, such as fairy tales, legends, hearsay, and even published stories.

In the texts examined, real events seem to function as narrative motifs for literary testimonies. They enrich the text not only with special meaning, but

116. Popular Memory Group, «Popular Memory», op. cit., p. 229. 
to a certain extent also with a kind of structure. The fact that both of the common themes are found in the same novel, $M \alpha \tau \omega \mu \varepsilon^{\prime} v \alpha$ X $\omega \mu \alpha \tau \alpha$ written and published much later than the others, illustrates the literary exploitation of the specific narrative qualities. Both stories seem to carry the traditional functions of the fairy tale where a good man saves the life of a person in danger. In both narratives, there is the element of the fairy-like miraculous escape which has survived through folk tradition. Folklorists all over the world have tried to categorise the various folk tales and to make a type-list which helps researchers to recognise a tale and its version. Propp, in his book Morphology of the Folktale, abstracts the compositional pattern that underlies the structure of a fairy tale as a whole and enumerates the functions of the dramatis personae. ${ }^{117}$ According to his study, the above stories take the form of the tale where the hero is unjustly persecuted and finally rescued with the help of a magical agent who appears suddenly and is introduced as a gift. Thus, the passage from an initial disequilibrium to an equilibrium, which according to Todorov constitutes the structure of some fundamental narrative plots, ${ }^{118}$ is succeeded here by the qualities of a character, namely a good Turk. This assessment however, should not lead us to the assumption that the narrated events never happened. Rather they were enriched or transformed to a certain extent in order to fit the qualities of a good story and in this way to be able to survive through the years. Propp connects the evolution of the folk tale as a collective product in a community with the belated development of written literature and the wide sense of an oral epic tradition, characteristics which can also be detected in the nature of Greek culture. ${ }^{119}$

Nevertheless, the motif of the helpful Turk is exploited by literature to serve the writers' intentions. A good example for understanding the notion of selection at the second level of mediation is the first story, which refers to the incident with the doctor. In the oral testimony, the doctor is not a Turk but a European captive. By contrast, both literary testimonies emphasise the Turkish origins of the doctor. A fact which indicates the writers' intention to stress the mutual suffering and the common fate of the two people. Their

117. Vladimir Propp, Morphology of the Folktale, Austin and London 1968.

118. Tzvetan Todorov, The Poetics of Prose, Oxford 1977, pp. 108-119.

119. For the conflict between orality and textuality and the former's prevalence in Greek intellectual life see Dimitris Tziovas, «Residual Orality and Belated Textuality in Greek Culture and Literature», Journal of Modern Greek Studies 7 (1989), pp. 321-335. 
mutual suffering is further stressed in Venezis' text by the fact that the doctor's mother had been killed by Greek soldiers. It is not by chance that this information was added by the writer in the 1931 edition, when the book began to promote a pacifist message. ${ }^{120}$ The common fate underlined here through the mother figure is strongly linked with the dedication in Venezis' book $\Sigma \tau \dot{\eta} \nu$

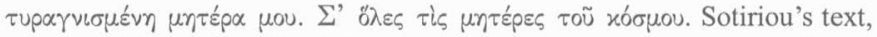

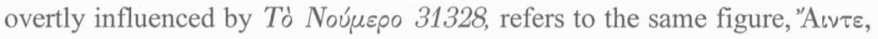

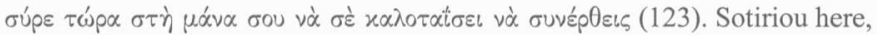
as in most parts of her novel, underlines the importance of reconciliation and stresses once more the imperialistic nature of all war. The writers' anti-war feelings are evident in all the literary texts. Doukas' testimony is also

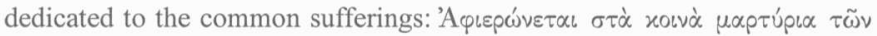
$\lambda \alpha \tilde{\omega} v$.

The recurring verbal motifs in the broader context of thematic similarities in these texts indicate that there are some 'speech incidents' which are conveyed through a community discourse, on which individuals draw to describe their personal experience. ${ }^{121}$ More specifically, all the texts underline the doctor's lies and devices which aim at helping the Greek. In the oral

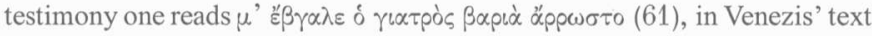

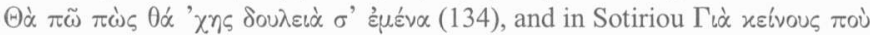

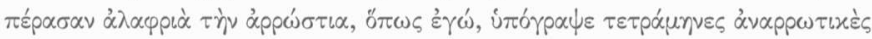
$\alpha \dot{\alpha} \delta \varepsilon \varepsilon \varsigma$ (123). However, the literary texts seem to stress even more the humanitarian behaviour of the doctor. The characterisation by the speaker of the oral testimony of a captain as a humanitarian ( $\alpha \nu \theta \rho \omega \pi \iota \sigma \tau \dot{\eta} \zeta)$ is applied in

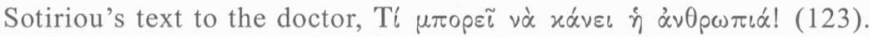
Furthermore, the presentation of a Turkish doctor as a Christian saint who

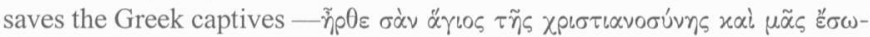
$\sigma \varepsilon(122)$ - strengthens even more the pacifist message of reconciliation that Sotiriou promotes. This message is also highlighted in the two literary texts by extended references not only to the acts, but also by references to the physical characteristics of the doctor and more specifically to his eyes which reflect his inner world and kindness. In this respect, in Tò Noúuspo 31328 one

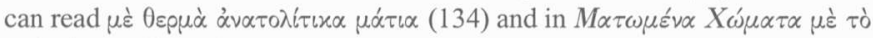

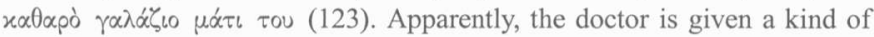

120. Di Salvo, Tò Noúuspo, p. 54.

121. Kopijn, «The Oral History Interview», op. cit., p. 145. 
magical and fabulous quality by the literary texts which seem to have drawn their material from the folk tale tradition.

In the second common story, the tendency to stress the characteristics of the good Turk is again evident. Here, not only does the Turk help a Greek by offering him a job, but he also regards him as a member of his family. The fact that a Muslim wants to include an Orthodox Christian in his family through the act of marriage could be regarded as unusual in relation to the religious ethics of Greek and Turkish societies, presented only in the oral testimony:

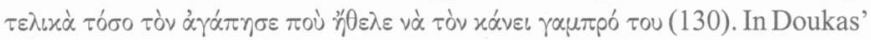
text one can trace verbal similarities to the oral testimony, for instance $\delta$

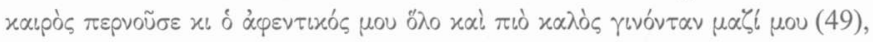

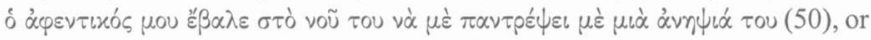

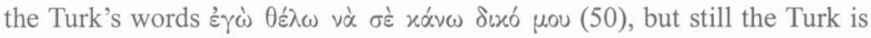
unaware of the Greek origins of his employee. Thus, the hypothesis that it is the early published literary text which, by establishing an oral tradition, has influenced people's narratives, is to some extent strengthened. One could link the element of marriage in the two testimonies with the fairy tale marriage with a bride who is usually given as a reward to the victimised hero for having come through a testing procedure. ${ }^{122}$ In Sotiriou's novel, however, the Turk does not wish to arrange a marriage between a Christian and a girl closely related to his family, although he treats the Greek like his own child. This attitude is underlined in the text by means of similar verbal motifs, $\delta$ répos

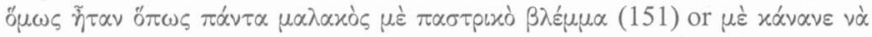

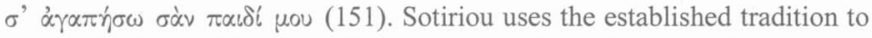
emphasise the need for reconciliation between the ordinary people of the two opposite camps in an explicitly didactic tone. In this light, the Turk, when talking to Manolis, draws parallels with his sons who also participate in the

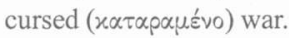

Since discourse is the medium through which experience and memory are organised, the full potential of a testimony lies also in the flow of social discourse. ${ }^{123}$ Verbal acts reflect not only the collective conceptualisation of the facts, but they also indicate the cultural aspect of social discourse. It is in this context that the repetition of identical phrases in the testimonies must be examined. More specifically, in the second common story the phrase $\varepsilon i \delta \alpha$

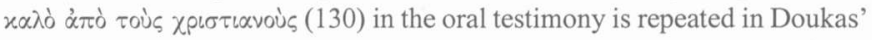

122. Propp, Morphology of the Folktale, p. 63.

123. Kopijn, op. cit., p. 142. 
text $\pi 0 \lambda \dot{\nu} x \alpha \lambda \grave{o} \varepsilon i \delta \alpha \alpha \dot{\alpha} \pi \dot{\partial}$ ' $\sigma \tilde{\alpha} \zeta$ (52 and 53). The repetition in the literary text does not seem to be a technique of an invented style, but has rather to do with the nature of oral discourse. In other words, the particular expression was probably a common phrase used in the everyday speech. In this way, the narrator's discourse, in an attempt to persuade the reader of its authenticity, reflects the latter's linguistic expectations. ${ }^{124}$ This tendency is indicative of the writers' professed intention to present not only facts but also the cultural dimensions of the collective discourse.

In conclusion, the recurrence of common thematics in the texts under discussion reveals that testimonies draw on myth and tradition at all levels of mediation. It can be inferred that the narrated events have actually occurred, since they have been related by witnesses, but they have been enriched or transformed in order to be exploited by literary texts. The selection of these stories from the literary texts serves the writers' intentionality to construct the collective nature of experienced events. Thus, literary testimonies present an individual's narrative by linking it with stories that make an appeal to people's consciousness. In addition, the discourse used reflects the collective discourse of those times. In other words, by using stories which demonstrate people's understanding vis-à-vis historical reality, the testimonies under discussion manage to link the individual with the collective conceptualisation of events. Oral history and fictionalised testimony both present the collective memory as it is established in and through tradition. In this way, history and memory are no longer distinctive disciplines but complementary to one another. In fact, they seem to 'collaborate' in giving the testimonial discourse

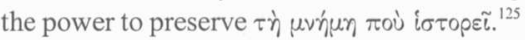

\section{Conclusion}

Both the oral and the literary testimonies under discussion demonstrate the way Greeks in Asia Minor experienced the Catastrophe of 1922. On the one hand, oral historians in ' $H$ ' $E \xi$ o $0 \delta$ s link the individual with the collective experience, which makes history by the accumulation of oral testimonies. On the other hand, literary authors present the single story, of a specific

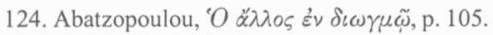

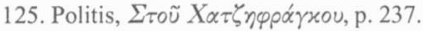


individual, setting it as a representative of a whole community. All the texts show faith in the ability of testimonial discourse to convey the collective experience. In that sense, the writers draw attention to two dimensions in the texts, the content, which is supposed to represent the truth about historical facts, and the discourse, which reflects the collective voice. In other words, the writers' intention is to demonstrate the collective experience by stressing what people say and how they talk about it. In this way, they introduce a combined historical and cultural reading.

The historical reading resembles the historian's factual reading of a source, since it is based on realist premises and it assumes that what is signified has some real existence outside the text. In this sense, the texts all show faith in the ability of language to denote the truth about the past and use the discourse of the witness as a way of reconstructing the past. All the texts aspire to let the events speak for themselves. A more careful reading however, reveals the limitations of both oral history and fictionalised testimony in conveying the unmediated voice of experience. П'́poós, a text which thematises the act of witnessing and testifying to the past, communicates the difficulty of the testimonial discourse in reconstructing the past through reminiscences. The effects of individual and collective memory, mingling together the real and the imaginary, come between the experienced events and their narrative, rendering the narrator subjective and often unreliable. The specific conditions of the interview and the interaction between the informant and the interviewer constitute another factor which often contradicts the accuracy of the witness. Furthermore, the professed accuracy and immediacy of testimonial discourse are often undermined by the writers themselves in the paratexts of the books. The narrator's discourse, as an act of construction which conveys the primary narrative of the event, and the intervention of both the historian and the literary author in transforming the oral testimony to a written text, introduce two different levels of mediation. As a result, what reaches the reader is not the unmediated voice of experience, but the mediated voice of the witness.

Regarding the fact that the material of testimony includes not only narrations, but also the dimensions of personal and collective memory, the narratives of ordinary people seem to be complex cultural products, as they draw on a wide range of genres. The existence of common stories both in oral and in literary testimonies stresses the presence of elements of fairy tale and legend in people's narratives. These stories present more than factually 
accurate accounts; they reveal the mental registration of an event in the collective memory. The reconstructing and telling of both collective and individual memory of the past is an active process which demands skill, art and imaginative power. In this sense, testimonies seem to be the mediated voices of collective conceptualisation of events and as such they reflect elements of folk tradition.

Bearing in mind that the mental registration of an event is itself an event, ${ }^{126}$ it could be suggested that the testimonies under discussion present a truth beyond the historical one, namely, the well-established truth of collective mentality and tradition. In this respect, both the oral and the literary testimonies underline the fact that the true power of testimonial discourse lies not in its adherence to the events, but rather in its deviation from them, where fantasy and symbolism intrude. Therefore, an alternative and supplementary reading of all the texts discloses the special value of oral sources as subjective and spoken testimonies. The elements of collective mentality and folk tradition are not communicated only through the popular charm of the discourse, but also through selected narratives that may not be reliable. Thus, despite the initial impression that testimonial discourse can reconstruct the past with accuracy, the historical truth always remains beyond its grasp and can only arrive at some approximation to it. What is actually reconstructed is the way the past is understood and preserved in the collective memory and in its expression, namely the tradition. The unreliability of the testimonies stresses even more the cultural reading that these texts introduce and its importance in discovering the traditions of the past.

126. Tonkin, Narrating our Pasts, p. 120. 